\title{
Human Recombinant Interleukin-1 $\beta$-mediated Growth Inhibition of Cultured Malignant Glioma Cells
}

\author{
Hisashi Koga, Jiro MUKawa, Koichi MiYagi, Yasushi Higa, \\ Susumu NAKASONE, Susumu MEKARU* and Marylou INGRAM* \\ Department of Neurosurgery, University of the Ryukyus School of Medicine, Okinawa; \\ *Experimental and Clinical Immunotherapy Laboratory, Huntington Medical \\ Research Institutes, Pasadena, Cal., U.S.A.
}

\begin{abstract}
The effect of human recombinant interleukin-1 $\beta$ (hrIL-1 $\beta$ ) on tumor growth was studied in eight glioma cell lines. hrIL-1 $\beta$ inhibited growth in all cell lines, but to varying extents. Two cell lines were suppressed by $0.5 \mathrm{ng} / \mathrm{ml}$ hrIL- $1 \beta$, and three cell lines required $20 \mathrm{ng} / \mathrm{ml}$. hrlL-1 $\beta$ also induced morphological changes and increased F-actin contents. hrIL- $\beta$-treated cells demonstrated multipolar shapes and numerous processes with a greater number of cell-cell contacts 24 hours after treatment. Fluorescence microscopy revealed that these processes contained a large amount of polymerized $\mathrm{F}$-actin. These results suggest that hrIL-1 $\beta$-mediated growth inhibition may be related to the differentiation of glioma cells.
\end{abstract}

Key words: malignant glioma, interleukin-1, actin, growth inhibition

\section{Introduction}

The cytokine interleukin-1 (IL-1) is produced by various cells including microglia" ${ }^{6}$ and glioma cells, ${ }^{4,5)}$ and displays a wide range of biological activities related to immunological response and cell proliferation. IL-1 causes growth inhibition in several malignant tumor cell lines such as A375, ${ }^{13,19)}$ K562, ${ }^{15}$ ) $\mathrm{L} 929,{ }^{19)}$ and $\mathrm{M} 1{ }^{20)}$ but promotes growth in human astrocytoma U373. ${ }^{(2)}$ No other glioma cell lines have been investigated.

Recently, clinical trials have assessed the effect of human recombinant IL-1 $\beta$ (hrIL-1 $\beta$ ) on malignant tumors including glioma. ${ }^{10,11)}$ Clinical inhibition was reported in malignant tumors, especially glioma, mammary carcinoma, and malignant lymphoma of the skin. These clinical results correlated with in vitro responses for mammary carcinoma and lymphoma. ${ }^{18,22)}$ IL-1 $\beta$ caused clinical inhibition of glioma, but growth promotion in vitro. ${ }^{12)}$ Here, we report a study of the direct effect of hrIL-1 $\beta$ on glioma cell proliferation to clarify the discrepancy in clinical and in vitro responses.

Received March 11, 1992; Accepted June 10, 1992

\section{Materials and Methods}

Five human glioblastoma cell lines were obtained from patients in the Huntington Memorial Hospital, Pasadena, Cal., U.S.A.: HBR9T\#2, HBR84T, HBR98T, O1T, and O9T. Two established human glioblastoma cell lines were provided by Dr. Higashi, Department of Neurosurgery, Okayama University Medical School, Okayama: T98G and KC-PC. One human glioblastoma cell line was obtained from a patient in Ryukyu University Hospital: RBR17T. The glial origin of cells was demonstrated by glial fibrillary acidic protein staining or standard histological criteria for cultured glial cells. Cells were maintained in Dulbecco's modified Eagle's medium (DMEM)/F12 (Flow Laboratories, Coasta Mesa, Cal., U.S.A.) supplemented with 5\% fetal bovine serum (FBS) (Flow Laboratories), neomycin (50 $\mathrm{mg} / \mathrm{l})$, and amphotericin B $(2.5 \mathrm{mg} / \mathrm{l})$. Cell lines were cultured in humidified air containing $5 \% \mathrm{CO}_{2}$ at $37^{\circ} \mathrm{C}$.

Growth inhibition was assessed by the ${ }^{3} \mathrm{H}$ thymidine incorporation assay. Glioma cell cultures were washed and adjusted to $1.0 \times 10^{4}$ cells $/ 200 \mu \mathrm{l}$ in DMEM/F12 supplemented with $5 \%$ FBS. This suspension was placed in 96-well, flat-bottomed 
plates at $200 \mu 1$ per well. The plates were incubated for 48 hours to allow recovery from trypsinization. The medium was then changed to fresh medium containing several dilutions of hrIL-1 $\beta(0.5-16 \mathrm{ng} / \mathrm{ml})$ (Otsuka Pharmaceutical Co., Tokyo). After 32 hour culture with hrIL-1 $\beta$, cells were pulsed with 0.2 $\mathrm{mCi} /$ well of ${ }^{3} \mathrm{H}$-thymidine ( $2 \mathrm{Ci} / \mathrm{mmol}$; Du Pont/ NEN Research Products, Wilmington, Del., U.S.A.) for a further 16 hours. The cells were harvested with a cell harvester, and the radioactivity incorporated measured by scintillation counter. Percentage growth inhibition was calculated by:

$$
100-\frac{\mathrm{cpm} \text { in target cells in medium with hrIL-1 } \beta}{\mathrm{cpm} \text { in target cells in medium alone }}
$$

Effect on doubling time was also evaluated. 0.5$2 \times 10^{5}$ cells were seeded in $35 \mathrm{~mm}$ tissue culture plates. Forty-eight hours later, the medium was changed with fresh medium, with or without hrIL-1 $\beta$ (10 or $20 \mathrm{ng} / \mathrm{ml}$ ). Forty-eight hours later, the medium was renewed. Cells were resuspended three times by brief treatment with an enzyme cocktail $(0.1 \%$ trypsin, $0.02 \%$ ethylene glycol-bis [ $\beta$-aminoethyl ether]-N,N,N'N'-tetra-acetic acid, $5 \%$ polyvinylpyrrolidone) and counted with a hemocytometer. The trypan blue dye exclusion method showed that viability was always greater than $95 \%$.

Cells were also analyzed by flow cytometry. $5 \times$ $10^{5}$ cells were seeded in $25 \mathrm{~cm}^{2}$ tissue culture dishes. Forty-eight hours later, the medium was changed to medium with or without hrIL-1 $\beta$ (10 or $20 \mathrm{ng} / \mathrm{ml})$. Forty-eight hours later, the cells were resuspended with the enzyme cocktail and fixed for 30 minutes in $2 \%$ cold paraformaldehyde. After washing with phosphate buffered saline (PBS), cells were permeabilized by $0.25 \%$ lysophosphatidyl choline (Sigma Chemical Co., St. Louis, Mo., U.S.A.) for 5 minutes. Permeabilized cells were then incubated for 45 minutes at $4^{\circ} \mathrm{C}$ with fluorescein isothiocyanate (FITC)-conjugated phalloidin (Sigma Chemical Co.) in the dark. The cells were rewashed and suspended in PBS for analysis by flow cytometer (Ortho
Cytoron; Ortho Diagnostic Systems K.K., Tokyo). Most experiments used $5 \times 10^{4}$ cells for analysis. To determine the changes in relative $\mathrm{F}$-actin content due to polymerization of F-actin (stress fibers) commonly observed in normal cells, ${ }^{23)}$ the mean channel intensities of hrIL- $1 \beta$-treated cells were compared with untreated cells.

Fluorescence microscopic analysis used glioma cells grown on slides and cultured with or without hrIL-1 $\beta$ (10 or $20 \mathrm{ng} / \mathrm{ml})$ for 48 hours. The slides were rinsed briefly in PBS and fixed, and cells permeabilized as above were then incubated for 45 minutes at $4^{\circ} \mathrm{C}$ with FITC-conjugated phalloidin in the dark. After rinsing in PBS, coverslips were mounted on slides and observed using an inverted microscope (Nikon, Tokyo) with epifluorescence optics.

Data are expressed as mean \pm SD and compared, where appropriate, with an unpaired Student's t-test. The data presented are representative of experiments performed in triplicate or greater.

\section{Results}

Table 1 shows that hrIL- $1 \beta$ at 10 or $20 \mathrm{ng} / \mathrm{ml}$ prolonged the doubling time of all human glioma cell lines. The ${ }^{3} \mathrm{H}$-thymidine incorporation assay also demonstrated growth inhibition. Figure 1 shows that five cell lines (O1T, O9T, HBR9T\#2, HBR84T, and HBR98T) demonstrated a maximum inhibition of ${ }^{3} \mathrm{H}$-thymidine uptake with only $0.5 \mathrm{ng} / \mathrm{ml}$ of hrlL$1 \beta$. One cell line (T98G) demonstrated dose-dependent inhibition of ${ }^{3} \mathrm{H}$-thymidine uptake. Two cell lines (KC-PC and RBR17T) showed only slight inhibition even at hrIL- $\beta$ concentrations of $16 \mathrm{ng} / \mathrm{ml}$. The data for these two cell lines were almost identical, with growth inhibition percentages for O1T and HBR84T of 77.0 and $66.7 \%$, respectively, causing marked changes in doubling time. In contrast, inhibition of KC-PC and RBR17T were 20.2 and $31.2 \%$, respectively, which left the doubling time unchanged in $10 \mathrm{ng} / \mathrm{ml}$ of hrIL-1 $\beta$.

Flow cytometry demonstrated changes in relative

Table 1 Doubling time (hrs) of glioma cells cultured with or without hrIL-1 $\beta$

\begin{tabular}{|c|c|c|c|c|c|c|c|c|}
\hline & $\mathrm{T} 98 \mathrm{G}$ & $\mathrm{KC}-\mathrm{PC}^{*}$ & $\operatorname{RBR} 17 T^{*}(15)$ & O1T (12) & O9T (9) & HBR9T $\# 2^{*}(13)$ & HBR84T (10) & HBR98T (14) \\
\hline Untreated & 24.1 & 15.9 & 33.2 & 84.3 & 80.6 & 21.6 & 28.6 & 31.9 \\
\hline hrIL-1 $\beta$-treated & 25.9 & 18.5 & 39.3 & 141.1 & 121.1 & 23.8 & 49.1 & 50.5 \\
\hline
\end{tabular}

. Numerals in parentheses indicate passage nos. Values are means of triplicate assays. SD was always $\pm 10 \%$. All times were significantly longer compared with untreated controls $(p<0.05)$. *These three cell lines were treated with $20 \mathrm{ng} /$ $\mathrm{ml}$ of hrIL-1 $\beta$, as $10 \mathrm{ng} / \mathrm{ml}$ had no effect on cell growth. 

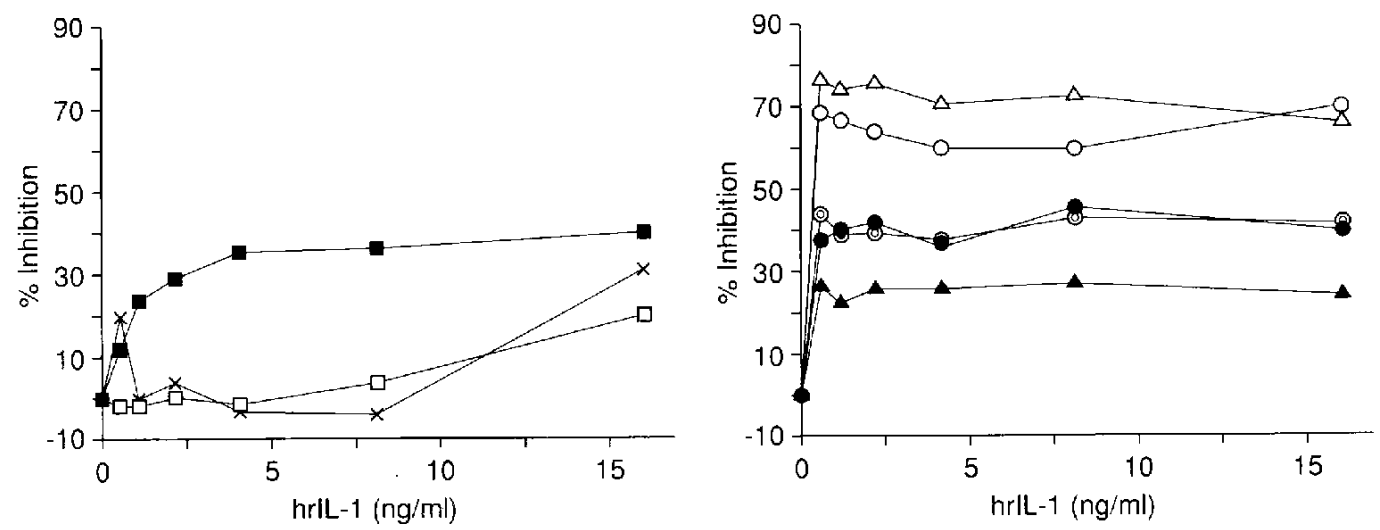

Fig. 1 hrIL-1 $\beta$-mediated growth inhibition of eight glioma cell lines. Results are mean of four or six cultures. SD was always $\pm 10 \%$. O: HBR84T, $\bullet$ : HBR98T, (9): HBR9T\#2, $\triangle:$ O1T, $\triangle:$ O9T, 口: KC-PC, $\square:$ T98G, $\times:$ RBR17T.
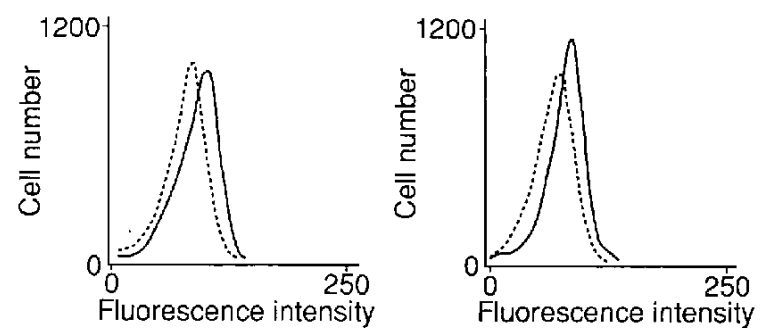

Fig. 2 F-actin histograms for O1T (left) and HBR84T (right). Profiles for untreated cells shown by dotted line and hrIL- $1 \beta$-treated cells by solid line.

F-actin content as mean channel intensity in the fluorescence histograms (Fig. 2). Mean channel intensities increased significantly compared with unexposed control cells except for KC-PC. Results reflected the growth inhibition assay; changes in O1T and HBR84T were prominent, but not in KC$\mathrm{PC}$ and RBR17T (Table 2).

Fluorescence microscopy showed profound hrIL$1 \beta$-induced alterations in cell morphology, especial- ly in O1T and HBR84T. HBR84T appeared epitheloid with short or no processes, but transformed to a multipolar shape with numerous processes and more cell-cell contacts 24 hours after hrIL- $1 \beta$ treatment. O1T had a polymorphic appearance, but became mainly bipolar (Fig. 3). Processes contained much polymerized $\mathrm{F}$-actin and an increased number of stress fibers appeared in the cytoplasm.

\section{Discussion}

In 1987 , Lachman et al. ${ }^{12)}$ reported that IL-1 promoted the growth of human astrocytoma U373 based on ${ }^{3} \mathrm{H}$-thymidine incorporation assay. Kasahara et $a l .^{8)}$ later found that IL-1-mediated proliferation was inhibited by pretreatment with low concentrations of cholera toxin $(<10 \mathrm{ng} / \mathrm{ml})$, and suggested that G protein-like molecules were involved in the early stages. They also demonstrated that $\mathrm{Ca}^{2+}$ mobilization and intracellular cyclic adenosine monophosphate level were not related to IL-1-mediated proliferation. IL-1 also acts as astrocyte growth factor both in developing and injured brains. ${ }^{7)}$ Clearly, IL-1 has no

Table 2 Flow cytometry analysis of F-actin content in glioma cells cultured with or without hrIL-1 $\beta$

\begin{tabular}{ccccccccc}
\hline & T98G & KC-PC* & RBR17T* (24) & O1T (17) & O9T (9) & HBR9T\#2* (13) & HBR84T (19) HBR98T (14) \\
\hline $\begin{array}{c}\text { Untreated } \\
\text { hrIL-1 } \beta-\end{array}$ & $84.6 \pm 0.2$ & $62.6 \pm 0.5$ & $32.4 \pm 0.7$ & $74.7 \pm 0.5$ & $81.3 \pm 1.4$ & $72.3 \pm 0.6$ & $63.5 \pm 1.0$ & $65.1 \pm 0.8$ \\
treated & $102.8 \pm 0.5$ & $62.1 \pm 0.3$ & $38.6 \pm 0.2$ & $86.7 \pm 0.8$ & $108.7 \pm 0.6$ & $82.6 \pm 0.1$ & $78.2 \pm 0.7$ & $84.1 \pm 0.8$ \\
\hline
\end{tabular}

Numerals in parentheses indicate passage nos. F-actin contents are expressed by mean channel intensities, rounded off, and expressed as mean \pm SD. Mean channel intensities were significantly greater compared with untreated controls ( $\mathrm{p}<0.001$ ) except for KC-PC. ${ }^{*}$ These three cell lines were treated with $20 \mathrm{ng} / \mathrm{ml}$ of hrIL-1 $\beta$, as $10 \mathrm{ng} / \mathrm{ml} \mathrm{had} \mathrm{no} \mathrm{effect}$ on cell growth. 


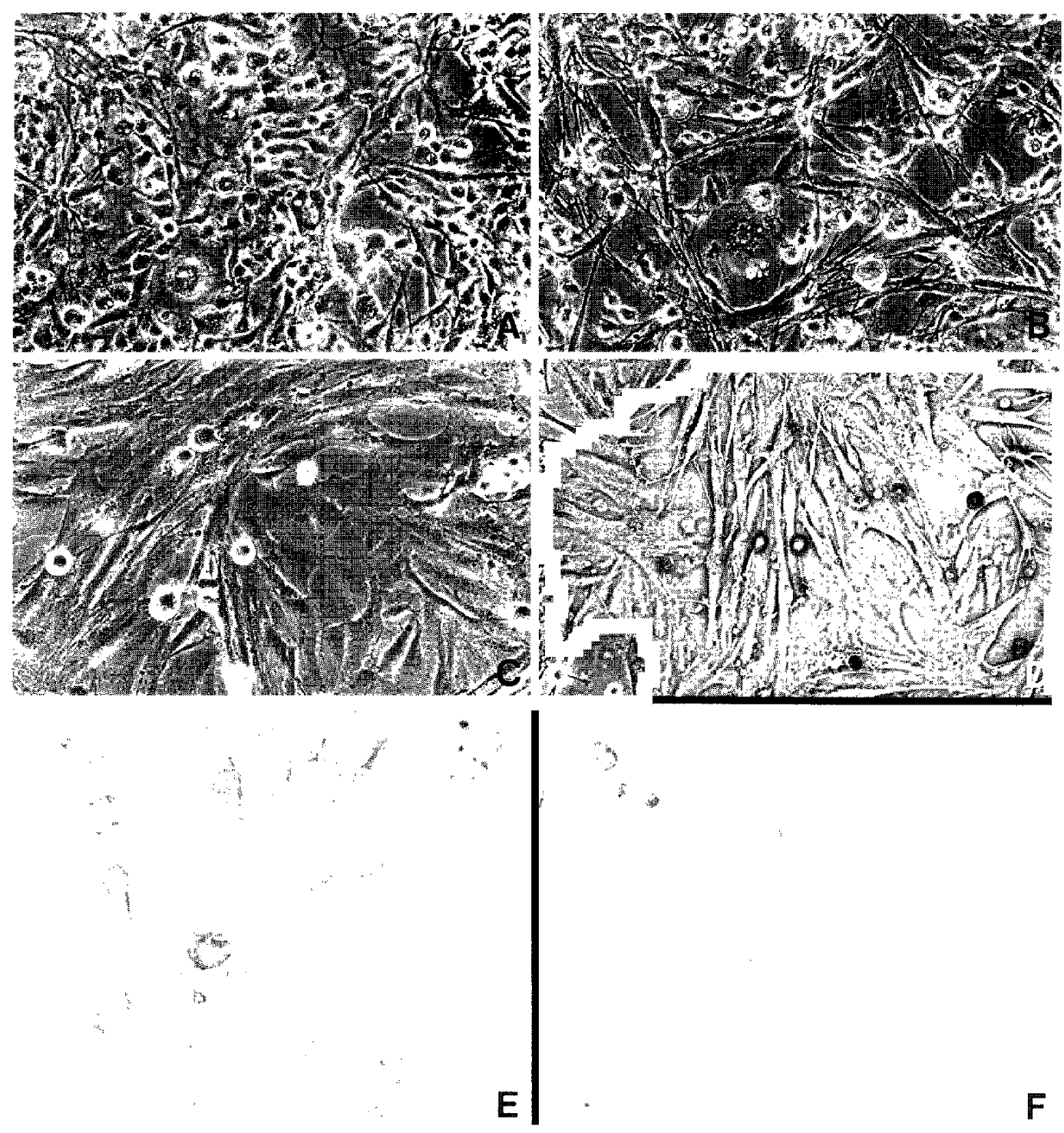

Fig. 3 A-D: Phase-contrast micrographs, showing morphological changes in O1T (A, B) and HBR84T (C, D). $\times 200$. E, F: F-actin distribution in O1T stained with FITC-conjugated phalloidin. $\times 200$. $A, C$, and $E$ are untreated and $B, D$ and $F$ are hrIL-1 $\beta$-treated cells.

therapeutic value in patients with malignant glioma.

However, IL-1 has cytocidal or cytostatic effects on other malignant cells. In 1987, Onozaki et al. ${ }^{20)}$ reported growth inhibition (maximum, $50 \%$ ) of mouse myeloid leukemic cell line (M1), possibly induced by terminal differentiation. In 1986, Lachman et $a l .{ }^{13)}$ reported a cytocidal effect on human melanoma cell line (A375). Endo et al. ${ }^{3)}$ suggested this cytocidal effect to be related to a decrease in ornithine decarboxylase activity. In 1988, Masuda et $a l{ }^{16)}$ reported that mitochondorial manganese superoxide dismutase was induced by $\mathrm{IL}-1$ in a human melanoma cell line (A325), which demon- strates IL-1-mediated growth suppression. Mitochondorial manganese superoxide dismutase induction was also observed in fibroblast and peripheral monocytes, in which IL-1 promotes growth. These data suggest that this phenomenon is common to IL-1 responder cells.

These experimental data have encouraged clinical phase study in Japan. ${ }^{10,11)}$ Significant responses have been observed in malignant glioma patients, possibly due to systemically augmented host anti-tumor immune defense mechanisms. ${ }^{1,18)}$ Diffuse infiltration of leukocytes $\left(\mathrm{CD}^{\circ} 5^{+}\right), \mathrm{B}$ cells, and natural killer cells $\left(\operatorname{Leu} 7^{+}\right)$was observed in a biopsy specimen from a 
malignant lymphoma patient treated with hrIL-1 $\beta$. Belardelli et al. ${ }^{1)}$ reported a marked increase in survival time and inhibition of metastasis due to subcutaneous IL- $1 \beta$ injection in mice with transplanted Friend leukemia cells. This response was suppressed by anti-T cell antibody. North et al ${ }^{18)}$ also reported that the in vivo effect of IL- $1 \beta$ did not occur in T celldeficient mice.

Our study investigated the reasons for the discrepancy in in vivo and in vitro responses. The direct effect of hrIL-1 $\beta$ on glioma cell proliferation showed all glioma cells to be inhibited. However, the extent of inhibition varied. KC-PC, RBR17T, and HBR9T \#2 needed high concentrations $(20 \mathrm{ng} / \mathrm{ml})$ of hrlL- $1 \beta$ before growth inhibition was induced, while O1T and HBR84T responded to low concentrations $(0.5 \mathrm{ng} / \mathrm{ml})$. The difference in response may be related to the number of hrIL- $\beta$ receptors in these cells,$^{3)}$ differences in intracellular second messenger, or heterogeneity in early passage. ${ }^{9)}$

The morphological changes involving numerous processes after hrIL- $1 \beta$ treatment resembled the terminal differentiation of normal astrocytes induced by acidic fibroblast growth factor, which contains base sequences homologous to IL-1. ${ }^{21)}$ Polymerization of F-actin also occurred in hrIL-1 $\beta$-treated glioma cells. The mechanism of this growth inhibitory effect may be related to the differentiation of glioma cells. In 1990, Lichtor et al. ${ }^{14)}$ reported significant expression of messenger ribonucleic acid encoding for IL- $1 \beta$ in a low-grade glioma but not in glioblastoma. They suggested that a decrease in IL-1 $\beta$ may correlate with tumor progression. In 1991, Nitta et al. ${ }^{17)}$ reported tumor necrosis factor- $\alpha$ gene expression in five glioma cell lines after stimulation with $100 \mathrm{U} / \mathrm{ml}$ of $\mathrm{IL}-1 \beta$. These phenomena may be also related to the growth inhibitory effect of IL- $1 \beta$.

This study showed that hrIL-1 $\beta$ inhibits the growth of glioma cells in vitro, suggesting that hrIL$1 \beta$ has therapeutic value in glioma patients. A further study is required to investigate immunological modulation and changes in blood flow in the tumor when IL-1 is administered systemically, as little is known about its effects in vivo., ${ }^{1,2,18}$

\section{Acknowledgments}

We thank Dr. Hisato Higashi, Department of Neurosurgery, Okayama University Medical School, Okayama, for providing us with human glioma cell lines. We are grateful to Ms. Kyoko Fujiwara for her excellent technical assistance.

\section{References}

1) Belardelli F, Ciollo V, Testa U, Montesoro E, Bulgarini D, Proietti E, Borghi P, Sestli P, Locardi C, Peschle C, Gresser I: Anti-tumor effects of interleukin-2 and interleukin-1 in mice transplanted with different syngeneic tumors. Int $J$ Cancer 44: 1108-1116, 1989

2) Braunschweiger PG, Johnson CS, Kumar N, Ord V, Furmanski P: Antitumor effects of recombinant human interleukin $1 \alpha$ in RIF-1 and Panc02. Cancer Res 48: 6011-6016, 1988

3) Endo Y, Matsushima K, Oppenheim JJ: Mechanism of in vitro antitumor effects of interleukin 1. Immunobiology 172: 316, 1986

4) Fontana $\mathrm{A}$, Hengartner $\mathrm{H}$, de Tribolet $\mathrm{N}$, Weber $\mathrm{E}$ : Glioblastoma cells release interleukin 1 and factors inhibiting interleukin 2-mediated effects. $J$ Immunol 132: $1837-1844,1984$

5) Fontana A, Kristensen F, Dubs R, Gemsa D, Weber $\mathrm{E}$ : Production of prostaglandin $\mathrm{E}$ and interleukin-1 like factor by cultured astrocytes and $\mathrm{C} 6$ glioma cells. J Immunol 129: 2413-2419, 1982

6) Giulian D, Baker TJ, Shin LN, Lachiman LB: Interleukin 1 of the central nervous system is produced by ameboid microglia. J Exp Med 164: 594-604, 1986

7) Hama T, Hatanaka H: Role of interleukins in CNS. Shinkei Kenkyu No Shinpo 34: 565-576, 1990 (in Japanese)

8) Kasahara T, Yagisawa H, Mukaida N, ShioiriNakano K: Signal requirements for ILl-induced BSF-2/IL6 production by a human astrocytoma cell line. Lymphokine Res 7: 276, 1988

9) Kilian PL, Kaffka KL, Biondi DA, Llpman JM, Benjamin WR, Feldman D, Campen CA: Antiproliferative effect of interleukin-1 on human ovarian carcinoma cell line (NIH: OVCAR-3). Cancer Res 51: 1823-1828, 1991

10) Kitamura K, Takaku H: A clinical phase study of IL1. Biotherapy 3: 1430-1437, 1989 (in Japanese)

11) Kitamura K, Takaku H: Clinical phase study of IL1及. Tanpakushitu Kakusan Koso 36: 1458-1465, 1991 (in Japanese)

12) Lachman LB, Brown DC, Dinarello CA: Growth-promoting effect of recombinant interleukin 1 and tumor necrosis factor for a human astrocytoma cell line. $J$ Immunol 138: 2913-2916, 1987

13) Lachman LB, Dinarello CA, Llansa ND, Fidler IJ: Natural and recombinant human interleukin $1-\beta$ is cytotoxic for human melanoma cells. $J$ Immunol 136 : 3098-3102, 1986

14) Lichtor T, Dohrmann GJ, Gurney ME: Cytokine gene expression by human gliomas. Neurosurgery 26: 788-793, 1990

15) Lovett D, Kozan B, Hadam M, Resch K, Gemsa D: Macrophage cytotoxicity: Interleukin 1 as a mediator of tumor cytostasis. J Immunol 136: 340-347, 1986

16) Masuda A, Longo DL, Kobayashi Y, Appella E, Op- 
penheim JJ, Matsushima K: Induction of mitochondorial manganese superoxide dismutase by IL-1. FASEB J 2: 3087, 1988

17) Nitta T, Steinman L, Sato K: Expression of cytokine genes within astrocytoma cell lines and brain specimens. No To Shinkei 43: 1145-1150, 1991 (in Japanese)

18) North RJ, Neubeuer RH, Huang LLH, Newton RC, Loveless SE: Interleukin 1-induced $T$ cell-mediated regression of immunogenic murine tumors. $J$ Exp Med 168: 2031-2043, 1988

19) Onozaki K, Matsushima K, Aggarwal BB, Oppenheim $\mathrm{JJ}$ : Human interleukin 1 is a cytocidal factor for several tumor cell lines. I Immunol 135: 39623968, 1985

20) Onozaki K, Tamatani $T$, Hashimoto $T$, Matsushima K: Growth inhibition and augmentation of mouse myeloid leukemic cell line differentiation by interleukin 1. Cancer Res 47: 2397-2402, 1987

21) Toru-Delbauffe D, Baghdassarian-Chalaye D,
Gavaret JM, Courtin F, Pomerance M, Pierre M: Effects of transforming growth factor $\beta 1$ on astroglial cells in culture. $J$ Neurochem 54: 10561061,1990

22) Tsai SCJ, Gaffney EV: Modulation of cell proliferation by human recombinant interleukin-1 and immune interferon. INCI 79: 77-81, 1987

23) Verderame $\mathbf{M}$, Alcorta D, Egnor $\mathbf{M}$, Smith $\mathrm{K}$, Pollack R: Cytoskeletal F-actin patterns quantitated with fluorescein isothiocyanate-phalloidin in normal and transformed cells. Cell Biology 77: 6624-6628, 1980

Address reprint requests to: H. Koga, M.D., Department of Neurosurgery, University of the Ryukyus School of Medicine, 207 Uehara, Nishihara-cho, Nakagami-gun, Okinawa 903-01, Japan. 